\title{
PENGEMBANGAN BAHAN AJAR BERORIENTASI PENDEKATAN SAINTIFIK PADA MATA KULIAH PEMBELAJARAN IPS SD DI PROGAM STUDI S1 PGSD
}

\author{
${ }^{1}$ Prima Rias Wana, ${ }^{2}$ Muhari, ${ }^{3}$ Waspodo Tjipto Subroto \\ ${ }^{1}$ Mahasiswa Program Pascasarjana, Prodi Pendidikan Dasar, Universitas Negeri Surabaya, \\ ${ }^{2 \& 3}$ Dosen Pascasarjana, Prodi Pendidikan Dasar, Universitas Negeri Surabaya \\ e-mail: riasprima7@gmail.com
}

\section{Received : Juli 2017}

Reviewed: Agustus 2017

Accepted : September 2017

Published : September 2017

\section{ABSTRACT}

This research had purpose to know of proper from development result of teaching material using scientific approach orientation in learning society (IPS) of Elementary School. The component validity consists of materials, presentation, languages, design, the implementation of learning, students learning outcome, and students respons. The type of this study is a research development. The development model used 4-D model (Four-D Model). The procedure is starting by defining development, design, and development. The subjects of this study are the students of S1 PGSD STKIP Modern Ngawi. 10 students (at the firts experiments ) and 32 students ( at second Experiments). Collecting data using observation, test, and questionnaires. The result of the study development result of teaching material using scientific approach orientation in learning society (IPS) of Elementary School are scoring from (1) the validity of the feasibility of component material, linguistic, and the presentation, also the validation from the expert's lectur so, the module of lesson are on decent category. (2)the teaching materials from SAP implemented excellent so it can support to increased learning activities. (3) The students give positive response and the average of cognitive achievement increases. The cognitive invidual students and classical result increase it's mean that it's accordance with the guidelines STKIP ratings Modern Ngawi. Based on the research of result we concluded that development of teaching material using scientific approach orientation in society learning (IPS) of Elementary School were proper, practical, and effective to improve the students learning outcome in College.

Keywords: Teaching Material, Scientific Approach, Society Learning (IPS).

\section{ABSTRAK}

Penelitian ini bertujuan untuk mengetahui kelayakan hasil pengembangan Bahan Ajar Berorientasi Pendekatan Saintifik dari validitas komponen materi, penyajian, kebahasaan, kegrafikan keterlaksanaan pembelajaran, dan hasil belajar serta respon mahasiswa. Jenis penelitian ini merupakan penelitian pengembangan. Model pengembangan yang digunakan adalah model 4-D (Four-D Model). Prosedur pengembangan dilakukan sampai tahap pendefinisian, perancangan, dan pengembangan. Subyek penelitian ini adalah mahasiswa S1 PGSD STKIP Modern Ngawi sebanyak 10 mahasiswa (ujicoba 1) dan 32 mahasiswa (ujicoba 2). Pengumpulan data menggunakan metode observasi, tes, dan angket. Hasil penelitian menunjukan bahwa data kualitas Bahan Ajar Berorientasi Pendekatan Saintifik pada Mata Kuliah Pembelajaran IPS yang dikembangkan dinilai dari (1) validitas kelayakan komponen materi, kebahasaan, penyajian serta kegrafikan dari hasil validasi yang dilakukan dosen ahli dengan kategori sangat layak. (2) bahan ajar dari keterlaksanaan SAP yang dilaksanakan dosen sangat baik yang mendukung peningkatan kegiatan pembelajaran. (3) respon mahasiswa ditanggapi dengan positif dan rata-rata hasil belajar kognitif meningkat. Ketuntasan hasil belajar mahasiswa secara individu maupun klasikal dapat tuntas sesuai dengan pedoman penilaian STKIP Modern Ngawi. Berdasarkan hasil penelitian diperoleh kesimpulan bahwa pengembangan Bahan Ajar Berorientasi Pendekatan Saintifik pada Mata Kuliah 
Pembelajaran IPS SD layak untuk meningkatkan hasil belajar kognitif mahasiswa di perguruan tinggi.

Kata Kunci : Buku Ajar, Pembelajaran Saintifik, Pembelajaran IPS SD.

\section{PENDAHULUAN}

Bahan ajar adalah segala bentuk bahan yang digunakan untuk membantu guru atau instruktor dalam melaksanakan kegiatan belajar mengajar di kelas. Bahan ajar memiliki posisi amat penting dalam pembelajaran, yakni sebagai representasi (wakil) dari penjelasan guru atau dosen di depan kelas. Keterangan-keterangan guru, uraianuraian yang harus disampaikan guru, dan informasi yang harus disajikan guru dihimpun di dalam bahan ajar. Dengan demikian, guru juga akan dapat mengurangi kegiatannya menjelaskan pelajaran, memiliki banyak waktu untuk membimbing siswa dalam belajar atau membelajarkan siswa (Zulkarnaini, 2009:1). Bahan ajar memiliki peran penting dalam sistem pendidikan nasional, karena dapat memberikan pengaruh besar terhadap kesatuan nasional melalui pendirian serta pembentukan suatu kebudayaan umum. Bahan ajar adalah bahan-bahan atau materi pelajaran yang disusun secara sistematis, yang digunakan guru dan siswa dalam proses pembelajaran (Pannen dalam Belawati, 2003:1.12). Pada kenyataannya bahan ajar yang digunakan tidak selalu sesuai dengan standar kelayakan baik kelayakan isi, bahasa, penyajian, maupun kegrafikan. Semua itu harus melalui beberapa proses pengkajian.

Dari uraian tersebut, Dosen/guru seharusnya mampu mengembangkan bahan ajar sendiri ajar sebagai salah satu sumber belajar lain di samping buku teks mahasiswa. Dalam Peraturan Pemerintah Nomor 19 Tahun 2005 Pasal 20, bahwa guru diharapkan mengembangkan materi pembelajaran dan melalui Permendiknas Nomor 41 Tahun 2007 tentang Standar Proses mengatur perencanaan proses pembelajaran bagi pendidik pada satuan pendidikan untuk mengembangkan SAP dan bahan ajar.

Dengan demikian, bahan ajar yang digunakan untuk mahasiswa harus terus dimutakhirkan dari segi strategi pembelajaran, isi, maupun bahasa agar sesuai dengan perkembangan pengetahuan dan kurikulum yang digunakan. Kurikulum yang sering berganti dalam waktu relatif cepat sebagai konsekuensi kebutuhan dunia pendidikan terhadap manusia sebagai subjek karya, karena itu belum tentu dapat diikuti dengan kecepatan pengadaan bahan ajar untuk mahasiswa.

Namun, pada kenyataanya buku ajar yang digunakan di beberapa perguruan tinggi masih terdapat kelemahan pada penyusunannya. Baik berdasarkan standar kelayakan isi, bahasa, penyajian, maupun kelayakan kegrafikaan.

Bahan ajar yang disusun secara sistematis dan menarik mencakup tentang: isi materi, metode, dan evaluasi yang dapat digunakan secara mandiri. Manfaatnya bagi mahasiswa digunakan secara mandiri, belajar sesuai dengan kecepatan masing-masing individu mahasiswa secara efektif dan efisien. Bagi dosen meningkatkan kreatifitas dosen, peningkatan profesionalisme dosen, peningkatan referensi dan intelektualitas untuk up to date, kontekstual dan mereaksi zaman, melatih dan mengembangkan ketrampilan menulis dosen sebagai ciri lembaga intelektual.

Pemanfaatan sumber belajar mempunyai pengaruh terhadap hasil belajar mahasiswa. Studi pendahuluan yang dilakukan di Program Studi S1 PGSD STKIP Modern Ngawi dalam pemanfaatan buku ajar untuk mata kuliah Pembelajaran IPS SD, mahasiswa hanya menggunakan buku teks bidang ilmu tertentu sebagai sumber belajar dengan hasil ketercapaian tujuan pembelajaran yang masih belum optimal, dikarenakan mahasiswa hanya mendapatkan sumber informasi dari buku teks saja. Dengan adanya bahan ajar perkuliahan ini diharapkan mahasiswa mampu belajar sesuai dengan kemampuanya dan kecepatan belajarnya.

Di samping itu, aktivitas mahasiswa dalam pembelajaran masih kurang aktif. Hasil wawancara dengan Ketua Progam Studi (Kaprodi) S1 PGSD STKIP Modern Ngawi, dan dosen pembelajaran IPS SD S1 PGSD STKIP Modern Ngawi, menjelaskan bahwa kurang aktifnya mahasiswa dalam kegiatan perkuliahan pembelajaran IPS SD salah satu penyebabnya adalah kurangnya sumber belajar yang digunakan mahasiswa di kelas dan belum adanya bahan ajar yang sesuai dengan materi perkuliahan sebagai sumber belajar mahasiswa. Saat ini, sumber belajar yang digunakan adalah buku teks bidang ilmu tertentu. Oleh karenanya, diperlukan bahan ajar yang sesuai dengan materi perkuliahan untuk memperluas wawasan pemahaman dan keterampilan mahasiswa tentang materi Pembelajaran IPS SD. Dengan wawasan pemahaman dan keterampilan yang luas mahasiswa dapat mengimplementasikan kemampuanya dengan baik dalam proses pembelajaran.

Berdasarkan uraian sebelumnya, peneliti berusaha menawarkan solusi dalam dalam mengahadapi 
permasalahan tersebut sehingga mengadakan penelitian berupa pengembangan bahan ajar berorientasi pendekatan saitifik pada mata kuliah pembelajaran IPS SD, yang diharapkan dapat meningkatkan kopentensi mahasiswa dan diharapkan mahasiswa mampu belajar mandiri sesuai dengan kemampuanya dan kecepatan belajarnya, serta dapat memahami secara baik materi yang ada pada mata kuliah pembelajaran IPS SD.

\section{METODE PENELITIAN}

Penelitian ini termasuk penelitian pengembangan (development research), karena mengembangkan bahan ajar yang diaplikasikan dalam pembelajaran pada mata kuliah Pembelajaran IPS SD. Penelitian ini berorientasi pembelajaran saintifik, yang memuat 2 unit materi dari bagian buku ajar pembelajaran IPS SD. Unit materi yang dikembangkan dalam penelitian ini adalah metode dan media dalam pembelajaran IPS. Di bidang pendidikan penelitian dan pengembangan merupakan penelitian yang dilakukan untuk mengembangkan produk-produk yang digunakan dalam bidang pendidikan dan pembelajaran (Borg and Gall dalam Sugiyono, 2008:4). Penelitian ini dilaksanakan di Program Sudi S1 PGSD STKIP Modern Ngawi pada semester genap tahun pelajaran 2015/2016. Yang menjadi subyek penelitian ini adalah pengembangan bahan ajar, sedangkan yang menjadi sasaran uji coba I adalah Mahasiswa PGSD kelas B dengan jumlah 10 Mahasiswa dan uji coba II adalah mahasiswa PGSD kelas A dengan jumlah 32 mahasiswa STKIP Modern Ngawi semester genap tahun pelajaran 2015/2016.

Proses pengembangan instrumen ini terdiri dari empat tahap yaitu define (pendefinisian), design (perancangan), develop (pengembangan), dan disseminate (penyebaran) atau diadaptasi menjadi Model 4-P, yaitu Pendefinisian, Perancangan, Pengembangan, dan Penyebaran. Pada penelitian ini hanya tiga tahap saja yang dilaksanakan yaitu: mendefinisikan, merancang, dan mengembangkan. sehingga yang telah dikembangkan digunakan pada kampus yang digunakan sebagai tempat penelitian tanpa disebarkan pada kampus lain.

Dalam penelitian ini, peneliti menggunakan empat teknik pengumpulan data yaitu validasi, observasi, angket, dan tes hasil belajar

\section{HASIL DAN PEMBAHASAN}

\section{Validitas Bahan Ajar}

Validasi bahan ajar dilakukan dengan maksud untuk mengetahui validitas bahan ajar yang dikembangkan. Bahan ajar yang dihasilkan, diserahkan kepada validator untuk divalidasi sebelum digunakan dalam tahap ujicoba.
Bahan Ajar yang dikembangkan oleh peneliti (draf 1) merupakan bahan ajar Pokok Bahasan Metode dan Media Pembelajaran IPS yang telah divalidasi oleh pakar untuk dievaluasi dan disempurnakan setelah digunakan pada uji coba 1 dan siap digunakan pada ujicoba di kelas. Komponen penilaian bahan ajar Pokok Bahasan Metode dan Media Pembelajaran IPS meliputi Kelayakan materi, kelayakan penyajian, kelayakan kebahasaaan dan kelayakan kegrafikan kemudian di telaah dan dinilai oleh validator.

Sesuai dengan saran dan masukan dari pakar, peneliti melakukan revisi kembali untuk memperbaiki dan menyempurnakan bahan ajar Pokok Bahasan Metode dan Media Pembelajaran IPS beserta perangkat pembelajarannya sesuai dengan masukan pakar tersebut dalam bentuk draf II. Dengan draf ini, kemudian bahan ajar Pokok Bahasan Metode dan Media Pembelajaran IPS yang dikembangkan beserta perangkat pembelajarannya dilakukan ujicoba II dengan 32 mahasiswa S1 PGSD STKIP Modern Ngawi

Berdasarkan tabel 4.1.a menunjukan bahwa rata-rata berdasarkan validasi komponen materi dan kebahasaan 3,37 presentasi 90,25\% valid dengan sedikit revisi. Sedangkan tabel 4.1.b menunjukan bahwa rata-rata berdasarkan validasi kelayakan penyajian dan kegrafikan 3.5 presentasi $87,5 \%$ valid dengan sedikit revisi.

Dari validasi bahan ajar di atas maka dapat disimpulkan bahan ajar Pokok Bahasan Metode dan Media Pembelajaran IPS berkategori sangat layak dalam komponen materi dan bahasa dan dapat dilanjutkan pada uji coba 1 dan ujicoba 2 .

\section{Validitas Silabus}

Berdasarkan Tabel 4.2 menunjukkan hasil penilaian validator $86 \%$ dari semua komponen silabus sudah valid dan $14 \%$ perlu perbaikan. Dengan demikian dapat disimpulkan silabus berkategori sangat layak dilanjutkan pada uji coba 1 dan 2 Terdapat beberapa saran perbaikan dari validator yang digunakan oleh peneliti untuk memperbaiki silabus.

\section{Validitas Satuan Acara Perkuliahan (SAP)}

Satuan Acara Perkuliahan (SAP) digunakan acuan untuk menggambarkan skenario penyajian materi pelajaran yang akan dilakukan oleh Dosen. Pada penelitian ini menjadi 4 kali pertemuan.

Berdasarkan Tabel 4.5, hasil penilaian dari validator 86\% dari semua komponen Satuan Acara Perkuliahan (SAP) sudah valid dan $12 \%$ perlu perbaikan, maka dapat disimpulkan silabus berkategori layak dilanjutkan pada uji coba 2. Terdapat beberapa saran perbaikan dari validator 
yang digunakan oleh peneliti untuk memperbaiki Satuan Acara Perkuliahan (SAP)

\section{Keterlaksanaan SAP menggunakan Bahan Ajar Pembelajaran IPS SD}

5. Berdasarkan Tabel 4.9.a di atas dapat diketahui bahwa kegiatan pembelajaran menggunakan strategi Pembelajaran Saintifik dalam rancangan bahan ajar Pokok Bahasan Metode dan Media Pembelajaran IPS pada uji coba 1 dilaksanakan sangat baik oleh Dosen, baik pada pertemuan 1 dan pertemuan 2 setiap kegiatan pembelajaran. Hal ini terlihat dari skor rata-rata dari pengamat lebih dari 3,0 pada setiap kegiatan pembelajaran. Rata-rata keterlaksanaan pembelajaran pada pertemuan 1 adalah 3,50 dan pada pertemuan 2 adalah 3,60.

Koefesien reliabilitas instrumen keterlaksanaaan pembelajaran oleh dosen pada pertemuan 1 adalah 87\%; pada pertemuan 2 adalah 90\%; Rata-rata koefesien reliabilitas keterlaksanaan pembelajaran pada kedua pertemuan adalah $90 \% \geq 75 \%$. Jadi instrumen tersebut dikategorikan sangat baik (Borich,1994).

Dari ujicoba 1 yang dilaksanakan dilanjutkan pada ujicoba 2 hasil pengamatan oleh masing-masing pengamat disajikan pada Tabel 1 sebagai berikut:

Tabel 1.

Hasil Pengamatan Ujicoba 2

\begin{tabular}{|c|c|c|c|c|c|c|c|}
\hline \multirow{2}{*}{$\begin{array}{l}\mathbf{N} \\
\mathbf{0}\end{array}$} & \multirow{2}{*}{$\begin{array}{c}\text { Kegiata } \\
\text { n } \\
\text { Pembel } \\
\text { ajaran }\end{array}$} & \multicolumn{2}{|c|}{ RPP 1} & \multicolumn{2}{|c|}{ RPP 2} & \multirow{2}{*}{$\begin{array}{c}\text { Rat } \\
\text { a- } \\
\text { Rat } \\
\text { a }\end{array}$} & \multirow{2}{*}{$\begin{array}{c}\text { Kateg } \\
\text { ori }\end{array}$} \\
\hline & & P1 & P2 & P1 & P2 & & \\
\hline 1 & $\begin{array}{l}\text { Tahap } \\
\text { Menga } \\
\text { mati }\end{array}$ & 4 & 4 & 4 & 4 & 3.67 & $\begin{array}{c}\text { Sangat } \\
\text { Baik }\end{array}$ \\
\hline 2 & $\begin{array}{l}\text { Tahap } \\
\text { Menany } \\
\text { a }\end{array}$ & 3 & 3 & 3 & 4 & 3.67 & $\begin{array}{c}\text { Sangat } \\
\text { baik }\end{array}$ \\
\hline 3 & $\begin{array}{l}\text { Tahap } \\
\text { Mengu } \\
\text { mpulkan } \\
\text { informa } \\
\text { si }\end{array}$ & 4 & 4 & 4 & 4 & 3.67 & $\begin{array}{c}\text { Sangat } \\
\text { baik }\end{array}$ \\
\hline 4 & $\begin{array}{l}\text { Tahap } \\
\text { Mengas } \\
\text { osiasi }\end{array}$ & 4 & 3 & 3 & 4 & 3.17 & $\begin{array}{c}\text { Sangat } \\
\text { Baik }\end{array}$ \\
\hline 5 & $\begin{array}{l}\text { Tahap } \\
\text { Mengo } \\
\text { munikas } \\
\text { ikan }\end{array}$ & 3 & 4 & 4 & 3 & 3.83 & $\begin{array}{c}\text { Sangat } \\
\text { Baik }\end{array}$ \\
\hline & Jumlah & 18 & 18 & 18 & 19 & 3.83 & \\
\hline & a-rata Skor & & & & & & \\
\hline & eliabilitas & & & & & & \\
\hline & $\begin{array}{l}\text { Rata-rata } \\
\text { eliabilitas }\end{array}$ & & & & & & \\
\hline
\end{tabular}

Berdasarkan Tabel 1. di atas dapat diketahui bahwa kegiatan pembelajaran menggunakan strategi Pembelajaran Saintifik dalam rancangan bahan ajar Pokok Bahasan Metode dan Media Pembelajaran IPS pada uji coba 2 dilaksanakan sangat baik oleh dosen, baik pada pertemuan 1 dan pertemuan 2 pada setiap kegiatan pembelajaran. Hal ini terlihat dari skor rata-rata dari pengamat lebih dari 3,0 pada setiap kegiatan pembelajaran. Rata-rata keterlaksanaan pembelajaran pada pertemuan 1 adalah 3,60 dan pada pertemuan 2 adalah 3,70

Koefesien reliabilitas instrumen keterlaksanaaan pembelajaran oleh dosen pada pertemuan 1 adalah $90 \%$ dan pada pertemuan 2 adalah 92\%. Rata-rata koefesien reliabilitas keterlaksanaan pembelajaran pada kedua pertemuan adalah $91 \% \geq 75 \%$. Jadi instrumen tersebut dikategorikan sangat baik (Borich,1994).

\section{Respon Mahasiswa}

Dalam menggunakan bahan ajar Pembelajaran IPS SD untuk menilai kualitas pembelajaran, salah satunya caranya dengan memberikan angket respon mahasiswa. Mahasiswa dikatakan memberikan respon positif jika memberikan pernyataan "Ya" terhadap angket respon yang diberikan. Mahasiswa dikatakan memberi respon negatif jika memberikan pernyataan "Tidak" terhadap angket respon yang diberikan.

Berdasarkan Tabel 4.10.a pada ujicoba 1 hasil analisis angket respon siswa dapat diketahui bahwa pembelajaran yang diterapkan dikelas memperoleh persentase respon positif siswa yang menjawab "Ya" sebanyak 93,\% dan persentase respon negatif siswa yang menjawab "Tidak" sebesar $7 \%$. Berdasarkan hasil data tersebut menunjukkan bahwa sebagian besar siswa memberikan respon positif. Hal ini berarti siswa merasa senang terhadap pembelajaran mengenai materi pelajaran, bahan ajar pembelajaran IPS SD, suasana belajar, dan cara dosen mengajar mahasiswa mudah memahami materi pada bahan ajar pembelajaran IPS SD dengan pokok bahasan metode dan media pembelajaran IPS. Mahasiswa tertarik dan memahami bahan Ajar tersebut, sehingga dalam proses pembelajaran yang akan dilaksanakan selanjutkan dapat menggunakan bahan ajar pembelajaran IPS SD tersebut. Sedangkan Berdasarkan Tabel 4.10.b pada ujicoba 2 hasil analisis angket respon siswa dapat diketahui bahwa pembelajaran yang diterapkan dikelas memperoleh persentase respon positif siswa yang menjawab "Ya" sebanyak 94\% dan persentase respon negatif siswa yang menjawab "Tidak" sebesar $6 \%$. Berdasarkan hasil data tersebut menunjukkan bahwa sebagian besar siswa memberikan respon positif. Hal ini berarti siswa merasa senang terhadap pembelajaran hari ini mengenai materi pelajaran, bahan ajar 
Pembelajaran IPS SD, suasana belajar, dan cara dosen mengajar mahasiswa mudah memahami materi pada bahar ajar tersebut dengan menggunakan penedekatan saintifik. Siswa tertarik dan memahami bahan ajar pembelajaran IPS , sehingga dalam proses pembelajaran yang akan dilaksanakan selanjutkan dapat menggunakan baha ajar tersebut.

Menurut teori belajar Gagne, belajar merupakan kegiatan yang kompleks. Hasil belajar berupa kapabilitas, setelah belajar orang memiliki keterampilan, pengetahuan, sikap, dan nilai. Timbulnya kapabilitas tersebut adalah dari stimulus yang berasal dari lingkungan dan proses kognitif yang dilakukan oleh pebelajar. Dengan demikian belajar adalah seperngkat proses kognitif yang mengubah sifat stimulasi lingkungan, melewati pengolahan informasi menjadi kapabilitas baru (Dimyati dan Mudjiono, 2006:10)

\section{Hasil Belajar Kognitif}

Berdasarkan Tabel 4.12.a hasil tes awal (pretest) dan Tabel 4.12.b hasil tes akhir (posttest) pada ujicoba 1 dan Tabel 4.13.a hasil tes awal (pretest) dan Tabel 4.13.b hasil tes akhir (posttest) pada ujicoba 2 maka didapatkan ketuntasan individual dan klasikal yang disajikan pada Tabel 2. sebagai berikut:

Tabel 2.

Ketuntasan Individual dan Klasikal

\begin{tabular}{ccccc}
\hline \multirow{2}{*}{ Aspek } & \multicolumn{2}{c}{ Uji coba 1 } & \multicolumn{2}{c}{ Uji coba 2 } \\
Rata-rata & Pretest & Pretest & Posttest & Pretest \\
Ketuntasan & $52(\mathrm{TT})$ & $95(\mathrm{~T})$ & $53(\mathrm{TT})$ & $95(\mathrm{~T})$ \\
Individual & & & & \\
Ketuntasan & $20 \%$ & $100 \%$ & $20 \%$ & $100 \%$ \\
Klasikal & $(\mathrm{TT})$ & $(\mathrm{T})$ & $(\mathrm{TT})$ & $(\mathrm{T})$ \\
\hline
\end{tabular}

Hasil Belajar kognitif dilakukan dengan metode tes. Hasil belajar merupakan tingkatan kemampuan mahasiswa yang diukur berupa penguasaan konsep sebagai hasil usaha individu terhadap apa yang telah dipelajari. Secara umum valiadtor memberikan penilaian terhadap tes penguasaan materi, dari segi isi, bahasa dan penulisan soal maupun konstruksi soal, namun ada beberapa indikator yang belum sesuai dengan soalnya, maka dilakukan revisi kecil untuk merubah sehingga sesuai dengan indikator yang dibuat dalam SAP.

Tes hasil belajar yang dikembangkan terdiri dari 20 soal pilihan ganda pada ujicoba 1. Berdasarkan hasil analisis data pada Tabel 4.12.a sebanyak 8 mahasiswa tidak tuntas ketika mengerjakan soal pretest. Pada ujicoba 2 hasil analisis data pada Tabel 4.12.a sebanyak 32 mahasiswa tidak tuntas ketika mengerjakan soal pretest Hal ini dikarenakan siswa belum mendapatkan pembelajaran yang akan mengunakan bahan ajar pembelajaran IPS SD. Hasil tes akhir (postest) diperoleh data bahwa seluruh siswa tuntas baik secara ketuntasan klasikal sebesar $100 \%$. Tujuan pembelajaran dikatakan tuntas jika proporsi nilai matakuliah yang dinyatakan dengan huruf $\mathrm{C}(\geq 61)$ adalah lulus, namun yang bersangkutan harus menempuh ujian perbaikan nilai. Hasil tersebut menunjukkan bahwa terjadi peningkatan hasil belajar mahasiswa antara sebelum dan sesudah pembelajaran dengan menggunakan bahan ajar pembelajaran IPS SD berorientasi pendekatan saintifik.

Keterlaksanaan pembelajaran tidak akan berjalan dengan baik tanpa didukung dengan perangkat pembelajaran yang baik. Perangkat pembelajaran meliputi silabus dan SAP, dan buku ajar. SAP yang digunakan harus sesuai dengan langkah-langkah saintifik dengan menggunakan bahan ajar pembelajaran IPS SD. Bahan ajar pembelajaran IPS SD merupakan sumber belajar berbentuk bahan ajar yang dipergunakan oleh mahasiswa untuk membantu tercapainya standar kompetensi, kompetensi dasar, dan tujuan pendidikan yang telah ditetapkan. Menurut Prastowo (2013:297), bahan ajar adalah seperangkat materi yang disusun secara sistematis secara tertulis yang menampilkan sosok utuh dari kompetensi yang akan dikuasai mahasiswa dan digunakan dalam proses pembelajaran sehingga tercapai tujuan pembelajaran. Lihua (2011:224) buku ajar atau bahan ajar di perguruan tinggi merupakan komponen integral dari manajemen mengajar. Penggunaan buku ajar atau bahan ajar dalam pembelajaran akan lebih baik jika dipadukan dengan strategi belajar mengajar yang sesuai, sehingga buku ajar dapat menjadi alat pengajaran yang efektif. Dalam hal ini pembelajaran dilakukan menggunakan langkah-langkah saintifik yang membuat mahasiswa sangat aktif ketika mengikuti proses pembelajaran.

Penelitian yang relevan terhadap penelitian yang dilakukan oleh Pangestu. (2014). Dalam penelitian "Pengembangan Buku Ajar Berorientasi Pendekatan Karakter Mata Kuliah Pembelajaran PKn SD di Program Studi S1 PGSD". Hasil penelitiannya menujukan bahwa buku ajar berorientasi pendekatan pendidikan karakter pada mata kuliah Pembelajaran PKn SD di Program Studi S1 PGSD yang diterapkan kepada mahasiswa adalah sangat layak untuk digunakan. penelitian tersebut membuktikan buku ajar atau bahan ajar di perguruan tinggi bisa meningkatkan hasil belajar mahasiswa. Hasil penelitian ini sesuai dengan pendapat serta teori-teori yang mendukung. Teori belajar Bruner menyarankan agar seorang dosen tidak hanya memikirkan bagaimana mahasiswa belajar tetapi juga bagaimana cara membantu mahasiswa untuk belajar yang terbaik. Hal ini sesuai dengan teori Piaget 
(dalam Budiningsih, 2012:35) bahwa struktur kognitif yang sudah dimiliki seseorang harus disesuaikan dengan informasi yang diterima. Di dalam kelas, mahasiswa diberi waktu untuk saling diskusi dengan teman- temannya, untuk saling bertukar informasi.

Berdasarkan implikasi teori yang dikemukakan Piaget, maka dapat disimpulkan bahwa bahan ajar adalah buku yang berisi uraian mata kuliah tertentu untuk membantu mahasiswa dalam mencapai kompetensi, kompetensi dasar dan tujuan pembelajaran yang disusun secara sistematis dan telah diseleksi berdasarkan tujuan pembelajaran, orientasi pembelajaran, dan perkembangan mahasiswa. Bahan ajar pembelajaran IPS SDberorientasi pendekatan saintifik merupakan sumber belajar yang efektif untuk mengajarkan materi IPS SD pada perguruan tinggi.

\section{PENUTUP}

\section{Simpulan}

1. Berdasarkan hasil penilaian validator menunjukkan bahwa, kualitas Bahan ajar pokok bahasan metode dan media pembelajaran IPS berorientasi pembelajaran saintifik memiliki kualitas baik, sehingga layak untuk digunakan dalam pembelajaran.

2. KeRespon mahasiswa terhadap bahan ajar pokok bahasan metode dan media pembelajaran IPS berorientasi pembelajaran Saintifik yang di kembangkan sangat tinggi. Hal ini ditunjukkan oleh data tentang mahasiswa angket yang di berikan kepada mahasiswa.

3. Hasil belajar kognitif mahasiswa baik secara individual maupun klasikal. Hal ini dibuktikan dari hasil posttest pada ujicoba 2 di mahasiswa PGSD kelas A STKIP Modern Ngawi semua mahasiswa tuntas secara individu dengan rata-rata kelas 97 dan mengalami kenaikan sebesar $44 \%$ dari hasil pretest. Sedangkan ketuntasan klasikal posttest tuntas dengan presentase $100 \%$.

\section{Saran}

1. Perlu adanya koordinasi dan diskusi yang baik antara peneliti dan pengamat dengan tujuan untuk mencari masukan dan saran sehingga diperoleh kesamaan persepsi dalam rangka perbaikan untuk melaksankan pembelajaran selanjutnya.

2. Persiapan dan pengelolaan waktu perlu diperhatikan, karena penggunaan bahan ajar membutuhkan waktu relative lama dan agar mahasiswa lebih memahami akan materi yang disampaikan.

3. Untuk mendapatkan hasil yang efektif dalam proses penelitian, bahan ajar yang dikembangkan harus terdapat aspek motivasi, manfaat dan contoh yang mudah dipahami mahasiswa.

\section{DAFTAR PUSTAKA}

Belawati, Tian. (2003). Materi Pokok Pengembangan Bahan Ajar Edisi ke Satu. Jakarta: Universitas Terbuka

Borich, G.D. 1994. Observation Skill For Effective Teaching. New York: Macmillan Publishing Company.

BSNP. (2007). Kurikulum Tingkat Satuan Pendidikan. Jakarta: BSNP.

Dahar, Ratna Wilis. (1988). Teori-teori Belajar. Jakarta: Penerbit Erlangga

Depdiknas, (2006). Kurikulum Standar Isi. Jakarta.

Depdiknas, (2008). Panduan Pengembangan Buku Ajar. Jakarta.

Dimyati dan Mudjiono. (2006). Belajar dan Pembelajaran. Jakarta: Rineka Cipta.

Dick dan Walter Carey. (2005). The Systematic Design of Instruction. USA : Scott Foresman and Company.

Emin Kilinc. (2013). Pre-Service Social Studies Teachers' Understandings about the Nature of the Social Studies. International Electronic Journal of Elementary Education. International Electronic Journal of Elementary Education. Vol 6.2013

Endang Mulyani. (2004). Penerapan dalam bahan ajar dan LKS. Jurnal Ekonomi \& Pendidikan Vol 2.

Hamalik, Oemar. (2008). Dasar-dasar Pengembangan Kurikulum. Bandung: PT Remaja Rosdakarya.

Heather Leaman. (2009). Improving Learning Through Performance Assessment in a Social Studies Methods Course for Preservice Elementary Teachers. SRATE Journal Summer 2009, Vol. 18

Ibrahim, M. (2001). Pengembangan Perangkat pembelajaran. Jakarta: Departemen Pendidikan Nasional

Ibrahim, Muslimin. (2010). Dasar-dasar Proses Belajar Mengajar. Surabaya: Unesa University Press.

I Made Tegeh. (2014). Pengembangan Bahan Ajar Ips Berorientasi Ips Terpadu Untuk Siswa Smp Kelas VII. E-Journal Program Pascasarjana Universitas Pendidikan Ganesha Program Studi Teknologi Pembelajaran Volume 4.

Kurniasari.(2010). Pengembangan Buku Ajar Bahasa Indonesia bagi Anak Berkebutuhan Khusus (ABK) Siswa Kelas IV Sekolah Dasar. (Tesis magister tidak dipublikasikan). Universitas Negeri Surabaya. 
Muslich, Masnur. (2010). Texs Book Writing (Dasar-Dasar Pemahaman Penulisan, dan Pemakaian Buku Teks). Jogjakarta: Ar-ruzz Media.

Majid, A. (2001). Perencanaan Pembelajaran. Bandung: PT Remaja Rosdakarya.

Nasution. (1982). Berbagai Pendekatan Dalam Proses Pembelajaran dan Mengajar. Jakarta: Bina Aksara.

Nur, Mohamad. (2011). Modul Keterampilan-keterampilan Proses Sains. Surabaya: Universitas Negeri Surabaya Pusat Sains dan Matematika Sekolah

Nunuk kistyawati. (2014). Pengaruh regrouping dan motivasi belajar terhadap Prestasi belajar ilmu pengetahuan sosial siswa Kelas iv, v dan vi sekolah dasar. Elementary School Vol 1.

Pangestu, Widyo. (2014). Pengembangan Buku Ajar Berorientasi Pedidikan Karakter Pada Mata Kuliah Pkn SD Di Program Studi S1 PGSD.(Tesis magister tidak dipublikasikan). Universitas Negeri Surabaya

Peraturan Menteri Pendidikan dan Kebudayaan Republik Indonesia Nomor 81a Tahun 2013 Tentang Implementasi Kurikulum. (Online) http://urip.files.wordpress.com/2013/06/salinanpermendikbud-nomor-81a-tahun-2013-tentangimplementasi-kurikulum-garuda.pdf, diakses pada tanggal 2 Desember 2015.

Pujiati. (2007). Pengembangan Bahan Ajar Praktikum Pengantar Akuntansi. Jurnal Ekonomi dan Pendidikan. Vol. 4 No. 2.

Prastowo, Andi. (2013). Pengembangan Bahan Ajar Tematik. Jogjakarta: Diva Press.

Purwanto, N. 2004. Prinsip-prinsip dan Teknik Evaluasi Pengajaran. Bandung: PT Remaja Rosdakarya.

Riduwan, (2006). Metode dan Teknik Menyusun Tesis. Bandung: Alfabeta.

Rusman. (2012) Model-model Pembelajaran: Mengembangkan Profesionalisme Guru. Jakarta: Rajawali Press.

Sugiyono, (2008). Metode Penelitian Pendidikan Kuantitatif, Kualitatif dan R\&D. Bandung: Alfabeta

(2015). Metode Penelitian Pendidikan PendekatanKuantitatif, Kualitatif dan $R \& D$. Bandung: Alfabeta

Suaeri, Abdul Rajab.(2013). Pengembangan Buku Pelajaran Bahasa dan Sastra Indonesia Bermodel Bagus pada Semester Genap Kelas XI SMA. (Tesis magister tidak dipublikasikan). Universitas Negeri Surabaya.

Sudjana. (1999). Metode Statistik. Bandung: Taruna
Sundawa, D. (2006). Pembelajaran Dan Evaluasi Hasil Belajar IPS. Bandung: UPI PRESS.

Supiyanto, Yudi.( 2000). Buku Ajar Pendidikan Ilmu Pengetahuan Sosial. Tuban: FPIPS IKIP PGRI Tuban.

Tarigan, Henry Guntur. (1986). Telaah Kurikulum dan Buku Teks. Bandung: Angkasa

Trianto, (2007). Model Pembelajaran Terpadu dalam Tepri dan Praktek. Jakarta: Prestasi Pustaka publisher.

Trianto. (2007). Model-model Pembelajaran Inovatif Berorientasi Konstruktivistik. Jakarta: Perstasi Pustaka.

Trianingsih. (2007). Pengembangan bahan ajar untuk meningkatkan Pemahaman materi mata kuliah demografi teknik. Jurnal Ekonomi \& Pendidikan Vol 4.

Winataputra, U. S. (2008). Teori Belajar Dan Pembelajaran. Jakarta: Universitas Terbuka.

Sungkono, dkk. (2003). Pengembangan Buku Ajar. FIP UNY.

Sahin Dundar. (2015). Are Prospective Elementary School Teachers' Social Studies Teaching Efficacy Beliefs Related to Their Learning Approaches in a Social Studies Teaching Methods Course?. Australian Journal of Teacher Education. Vol 40.

Scott Lewis (2012). The mediating role of scientific tools for elementary school students learning about the Everglades in the field and classroom. International Journal of Environmental \& Science Education Vol. 7.

Senler. B. (2015). Middle School Students' Views of Scientific Inquiry: An International Comparative Study. Science Education International Vol. 26, Issue 2, 2015

Supriya. (2009). Pendidikan IPS Konsep dan Pembelajaran. Bandung: Remaja Rosda Karya

Suyono, (2011). Belajar dan Pembelajaran. Bandung: PT Remaja Rosdakarya

Ziya.Killic (2015). Effect of Scientific Argumentation on the Development of Scientific Process Skills in the Context of Teaching Chemistry. International Journal of Enviromental \& scince Education Vol. 10. 2015 